\title{
Polymorphism of MC4R gene associated with feed intake, nutrient digestibility, ADG and FCR at post-weaning in Bligon goats
}

\author{
L. Latifah ${ }^{1}$, D. Maharani ${ }^{1}$, K. Kustantinah ${ }^{2}$ and T. Hartatik ${ }^{1}$,* \\ ${ }^{1}$ Department of Animal Breeding and Reproduction, Faculty of Animal Science, \\ Universitas Gadjah Mada, Jl. Fauna No.3, Yogyakarta - Indonesia \\ ${ }^{2}$ Department of Animal Nutrition and Feed Science, Faculty of Animal Science, \\ Universitas Gadjah Mada, Jl. Fauna No.3, Yogyakarta - Indonesia \\ *CorrespondingE-mail: tety@ugm.ac.id
}

Received December 06, 2019; Accepted May 31, 2020

\begin{abstract}
ABSTRAK
Gene melanocortin 4 receptor (MC4R) memainkan peran penting pada aktivitas syaraf, adrenal, fungsi tiroid dan mediasi efek leptin dalam keseimbangan energi. Penelitian ini bertujuan untuk mengetahui efek 642 bp gen MC4R pada feed intake, kecernaan nutrien, pertambahan bobot badan harian (PBBH) dan feed conversion rate (FCR) pada kambing Bligon pasca sapih. Sebanyak 46 ekor kambing Bligon yang memiliki data diambil sampel darahnya kemudian diisolasi deoxyribo nucleic acid (DNA) menggunakan Geneaid isolation kit. Data feed intake dikoleksi pada 2 tempat yang berbeda yaitu di Laboratorium Fakultas Peternakan (LFP) UGM $(n=23)$ dan Banyusoco $(n=23)$. Variabel yang diamati yaitu feed intake, kecernaan nutrien, PBBH dan FCR. Penentuan genotip menggunakan metode PCRRFLP dengan enzim Kpn1 pada semua sampel kambing Bligon. Hasil penelitian menunjukkan terdapat satu polimorfisme di ekson (g.1079C/T). Analisis T-tes menunjukkan adanya asosiasi yang signifikan antara single nucleotide polymorphism (SNP) g.1079C/T dan kecernaan BK, bahan organik (BO) dan TDN pada kambing Bligon umur 7 bulan yang dipelihara di LFP UGM, sementara pada kambing Bligon yang dipelihara di Banyusoco terdapat perbedaan pada kecernaan bahan kering (BK), PK, ETN dan total digestible nutrient (TDN). Hasil penelitian dapat disimpulkan bahwa SNP g.1079C/T dapat digunakan untuk penentuan genotip kambing Bligon dan MAS untuk kecernaan nutrien.
\end{abstract}

Kata kunci : MC4R, Kambing Bligon, Feed intake, FCR, sifat pertumbuhan

\section{ABSTRACT}

The melanocortin-4 receptor (MC4R) gene plays an important role in sympathetic nerve activity, as well as adrenal and thyroid function and mediates the effects of leptin on energy homeostasis. This study aimed to investigate the effect of the $642 \mathrm{bp} \mathrm{MC4R}$ gene on feed intake, nutrient digestibility, average daily gain (ADG), and feed conversion ratio (FCR) at postweaned in Bligon goat. Forty-six Bligon were used for the blood sample collection, and genomic DNA was extracted using the Geneaid isolation kit. Feed intake data were collected on 46 Bligon goats kept on 2 different animal houses, including the laboratory's farm of Faculty of Animal Science Universitas Gadjah Mada (FAS UGM) with $n=23$ and Banyusoco farm $(n=23)$. Variables observed were feed intake, nutrient digestibility, ADG, and FCR. All samples were genotyped using the PCR-RFLP method with the KpnI enzyme. One SNP was located in the exonic region (g.1079C/T). The t-test analysis revealed a significant association between SNP 
g. $1079 \mathrm{C} / \mathrm{T}$ and the digestibility of dry matter (DM), organic matter (OM), and total digestible nutrient (TDN) of Bligon goats at 7 months of age kept on FAS UGM, as well as the digestibility of DM, crude protein (CP), nitrogen-free extract (NFE), and TDN of Bligon goats at 7 months of age kept on Banyusoco. In conclusion, it is possible to use SNP g.1079C/T for animal genotyping and as a MAS for nutrient digestibility in Bligon goats

Keywords: MC4R, Bligon Goat, Feed intake, FCR, ADG

\section{INTRODUCTION}

Bligon is a crossbred goat derived from Kacang and Etawah. Bligon goats are kept by many smallholder farmers because of their good productivity and adaptability to the harsh environment and therefore, an effort to improve the productivity of the goats is important, especially for genetic improvement strategies through selection. In the conventional breeding method, some measures such as estimated breeding values (EBV) and most probable producing ability (MPPA) are commonly used as consideration in animal selection (Hardjosubroto, 1994). However, selection using this method is based on physical appearance, without understanding which genes are being selected. Although goat selection programs in Indonesia commonly apply conventional breeding methods, the use of genetic markers seems like a promising way in genetic improvement strategies.

Currently, single nucleotide polymorphisms (SNPs) are applied as genetic markers in the selection program of many domesticated animals around the world, and many polymorphisms have been found in various candidate genes including melanocortin-4 receptor (MC4R). MC4R gene plays a vital role in regulating feed intake and energy homeostasis in mammals (Dubern, 2015). Many of the identified SNPs within the MC4R gene in mammals are reported to be nonsynonymous which can alter amino acids (Wang et al., 2015; Latifah et al., 2018). MC4R gene polymorphisms have been reported to be associated with body weight, ADG, FCR, and feed intake in pigs (Schroyen et al., 2015; Melnikova et al., 2018; Panda et al., 2019); growth traits in cattle (Maharani et al., 2018; Prihandini et al., 2019); body weight and body size in sheep (Song et al., 2012; Wang et al., 2015; Shishay et al., 2019).

In our previous study, two SNPs (g.988A/G and g.1079C/T) were identified in the exonic region of the MC4R gene of Bligon goats (Latifah et al., 2018). Single nucleotide polymorphism
SNP g.998A/G significantly influences weaning weight, weaning body length, and weaning heart girth while SNP g.1079C/T significantly affects weaning and pre-weaning weight. Many studies mentioned that the MC4R gene could be used as a candidate marker in the selection program for growth traits (Latifah et al., 2018; Maharani et al., 2018; Prihandini et al., 2019) and feed intake (Schroyen et al., 2015; Melnikova et al., 2018; Panda et al., 2019). Accordingly, this study explored the possibility of MC4R gene polymorphism as a marker-assisted selection (MAS) for feed intake at post-weaning in Bligon goats. This study aimed to investigate the effect of $642 \mathrm{bp}$ MC4R gene on feed intake, nutrient digestibility, ADG, and FCR at post-weaning Bligon goats.

\section{MATERIALS AND METHODS}

\section{Blood Samples Collection and DNA Extraction}

A total of 46 blood samples were collected from the jugular vein of Bligon goats. The blood samples were maintained into tubes containing K2EDTA. The blood sampling was according to the ethical clearance with no. 0103/EC$\mathrm{FKH} /$ Eks./2019. Blood samples were extracted using gSYNC ${ }^{\mathrm{TM}}$ DNA Extraction Kit (Geneaid, New Taipei City, Taiwan).

\section{PCR-RFLP}

Polymerase chain reaction (PCR) reagent was set up in a $30 \mu \mathrm{L}$ reaction volume containing $12 \mu \mathrm{LMybq}$ Mix, $9.5 \mu \mathrm{L}$ double-distilled water, $0.50 \mu \mathrm{L}$ of each primer (PF2: 5'TCGGGCGTCTTGTTCATCAT-3 and PR2: 5 'CAAGACTGGGCACTGCTTCA -'3), and $2 \mu \mathrm{L}$ of genomic DNA. The PCR conditions were as follows: initial denaturation at $94^{\circ} \mathrm{C}$ for $5 \mathrm{~min}$, followed by 35 cycles of denaturation at $94^{\circ} \mathrm{C}$ for $30 \mathrm{~s}$, annealing at $59.75^{\circ} \mathrm{C}$ for $30 \mathrm{~s}$, extension at $72{ }^{\circ} \mathrm{C}$ for $30 \mathrm{~s}$, with a final extension at $72{ }^{\circ} \mathrm{C}$ for $10 \mathrm{~min}$. The PCR-RFLP was used for animal genotyping based on MC4R gene polymorphism. The digestion was performed in a $9 \mu \mathrm{L}$ reaction 
mixture containing $4 \mu \mathrm{L}$ PCR products, 0.2 $\mu \mathrm{LKpnI}$ restriction enzyme, $3.3 \mu \mathrm{L} \mathrm{ddH}_{2} \mathrm{O}$, and $1.5 \mu \mathrm{L}$ buffer 1.1 . The digestion mixtures were incubated at $37^{\circ} \mathrm{C}$ for 3 hours, and then electrophoresis was performed in 3\% agarose gel, 50 volts for 60 minutes.

\section{Evaluation of Feed Intake}

Determination of body weight. Body weight was measured using a hanging scale with an accuracy of $0,01 \mathrm{~g}$ and carried out at the beginning and the end of feed observation. The data used for the calculation of feed conversion ratio (FCR).

Feeding. Animals were kept on individual cages. Diets were provided twice daily in the morning (08.00-09.00) and afternoon (15.0016.00). Drinking water was available ad libitum.

Feeding in the Faculty of Animal Science cage. A total of 23 goats (4-months old), with an average initial body weight of $11.38 \pm 2.34 \mathrm{~kg}$, and 20 goats (7-months old) with an average initial body weight of $18.40 \pm 2.55 \mathrm{~kg}$ were used. Diets contained king grass, calliandra, and concentrate as a source of protein. The amount of dietary supplementation was determined according to the daily protein requirements (gram/DM) of each individual according to their body weight, as presented in Table 1 . The nutrient requirements of goats were determined according to the NRC (1981). Diets were formulated to increase the daily weight of $100 \mathrm{~g}$. The final weight after the treatment was $12.84 \pm 2.41$ (4months) and 20.05 \pm 2.02 (7-months).

Feeding by the farmer in Banyusoco Village. A total of 23 post-weaned (4 and 7 months) with an average body weight of $11.31 \pm$ $2.11 \mathrm{~kg}$ and $12.93 \pm 2.09 \mathrm{~kg}$, respectively, were used in this study. Diets were given according to each livestock farmers. Before feeding, diets were weighed according to the forage species. The amount of feed intake data used was associated with genotype only 16 of data in the post-weaned period. The final weight in this study was $12.39 \pm 2.29$ for 4 -months and $13.54 \pm 2.06$ for 7 months.

\section{Variables Observed}

Chemical composition of feed. Feed samples, feed residues, and feces were analyzed for their chemical composition by proximate analysis (AOAC, 2005)

Feed intake. Feed intake was measured as dry matter (DM), organic matter (OM), crude protein $(\mathrm{CP})$, extract ether (EE), crude fiber (CF), nitrogen-free extract (NFE) and total digestible nutrient (TDN). Feed intake was determined according to the formula of Tilman et al. (1998), as follows:

Nutrient intake $(\mathrm{g})=$ nutrient in the supplied feed (g) - a nutrient in the leftover feed $(\mathrm{g})$

Nutrient digestibility. Nutrient digestibility was determined based on the amount of nutrient intake (in DM) minus the number of fecal nutrients (in DM). The digestibility measured in this study was DM, OM, CP, EE, CF, NFE, and TDN. Nutrient digestibility was calculated according to the following formula (Tillman et al. (1998):

Nutrient digestibility $(\%)=$ (amount of digestible nutrient)/(amount of nutrient

Table 1. The amount of Dietary Supplementation (g DM/day)

\begin{tabular}{lcc}
\hline \multirow{2}{*}{ Feed Ingredient } & \multicolumn{2}{c}{ Feed Offered Based on the Group of Age (g DM/day) } \\
\cline { 2 - 3 } & 4-months of age & 7-months of age \\
\hline Concentrate & 259 & 345 \\
Calliandra & 105 & 129 \\
King grass & 169 & 410 \\
Nutrient composition (\%) & & \\
Crude protein (CP) & 14.58 & 12.36 \\
Extract eter (EE) & 1.53 & 1.28 \\
Crude fiber (CF) & 13.64 & 16.56 \\
Total digestible nutrient (TDN) & 80.78 & 69.65 \\
\hline
\end{tabular}


consumed)] x 100

Daily weight gain. The daily weight gain was determined according to the following formula:

$$
\operatorname{ADG}(\mathrm{g} / \text { day })=(\mathrm{IBW}-\mathrm{FBW}) / \text { days }
$$

Where ADG is daily weight gain (g/day), IBW is initial body weight $(\mathrm{g}), \mathrm{FBW}$ is final body weight (g)

Feed conversion ratio. Feed conversion ratio (FCR) was calculated according to the following formula:

$$
\mathrm{FCR}(\%)=[\mathrm{DMI}(\mathrm{g}) / \mathrm{ADG}] \times 100
$$

Were FCR is feed conversion ratio, DMI is dry matter intake, ADG is average daily gain.

\section{Statistical analysis}

The effect of MC4R genotype on feed intake nutrient digestibility, ADG and FCR was analyzed using an independent sample t-test because the genotype of Bligon in this study detected only two genotipe. The mathematical model as follows:

$$
t=\frac{\bar{x}_{1}-\bar{x}_{2}}{S p \sqrt{\frac{1}{n_{1}}+\frac{1}{n_{2}}}}
$$

Were is mean value of the observed trait in the first genotype, is the mean value of the observed trait in the second genotype, $\mathrm{Sp}$ is the standard deviation, $\mathrm{n}_{1}$ is the total sample in the first genotype, $\mathrm{n}_{2}$ is total sample in the second genotype (Astuti, 1980)

\section{RESULTS AND DISCUSSIONS}

\section{Genotype determination using the PCR-RFLP method}

Latifah et al. (2017) reported two SNPs in the exon region (g.998A/G and g.1079C/T). Those SNPs detected using the direct sequencing method. In this study found an SNP g.1079C/T. The nucleotide sequence of the MC4R gene (642 bp) in Bligon goat was submitted into GenBank Acc. No. MN 635657 to MN 635660 (ID2278163). To genotype all individuals, the PCR products of the MC4R gene with 642 bp in length, were digested using $K p n \mathrm{I}$ restriction enzyme, and as a result, SNP g.1079C/T was detected. The digestion of PCR products generated two genotypes: 165 and $642 \mathrm{bp}$ fragments of genotype CC; and 165, 477, and 642 bp fragments of genotype CT (Figure 1). Two genotypes of the MC4R gene in Bligon goat were identified using PCR-RFLP. The use of restriction enzymes for animal genotyping based on SNP identified in the MC4R gene has been widely used in mammals. Latifah et al. (2017) reported three recommendations of restriction enzymes for genotyping Bligon goat based on the SNP g.1079C/T MC4R gene (Kpn1 (G_GTAC'C), Rsal (GT'AC), and Acc651 (G'GTAC C C)). The pattern of restriction enzyme $K p n 1$ resulted in three bands for SNP g.1079C/T. Wang et al. (2015) genotyped 3 SNPs identified in the MC4R gene of $\mathrm{Hu}$ sheep and Hu-East Friesian crossbred sheep using three different restriction enzymes (Msp1 for SNP g.306G/A, Nde1 for SNP

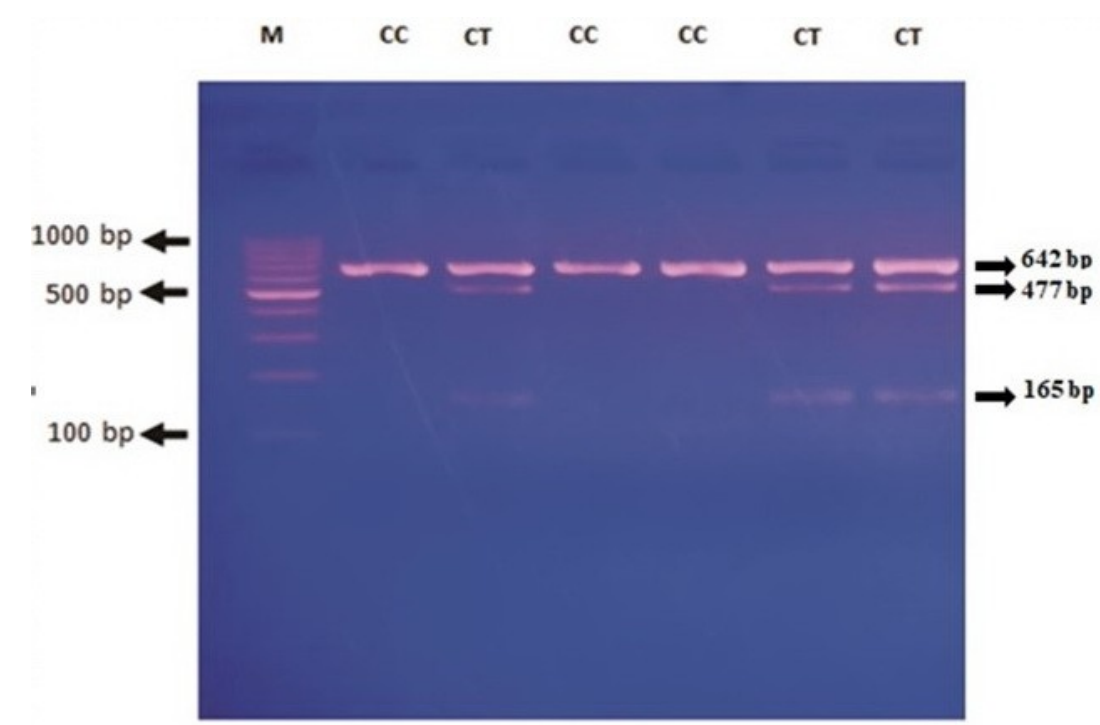

Figure 1: The electrophoresis pattern of g.1079C/T locus inBligon MC4R gene produced two genotypes $(\mathrm{CC}=165$ and $642 \mathrm{bp} ; \mathrm{CT}=165,477$ and $642 \mathrm{bp}$ ) 
g.1267G/A and Kpn21 for SNP g.706C/A). The genotype of MC4R is used for study association with feed intake nutrient digestibility, FCR, and ADG in Bligon goat.

Association between MC4R Genotype and Feed Intake, Nutrient Digestibility, FCR, and ADG in Post-weaned Bligon Goat

Two SNPs (g.988A/G and g.1079C/T) were detected in the MC4R gene of Bligon goat. The SNP g.988A/G had a significant effect on weaning weight, weaning body length, and weaning heart girth $(\mathrm{P}<0.05)$, in which animals with GG genotype had higher growth performance than those with $\mathrm{AA}$ and $\mathrm{AG}$ genotypes. The SNP g.1079C/T was found to be significantly associated with weaning and preweaning weight $(\mathrm{P}<0.05)$, in which animals with $\mathrm{CC}$ and $\mathrm{CT}$ genotypes had higher weaning and pre-weaning weight than those with TT genotype (Latifah et al., 2018).

In the present study, the association analysis of MC4R genotype with feed intake, nutrient digestibility, FCR, and ADG is presented in Table 2 and Table 3. The statistical analysis results showed that $\mathrm{CC}$ genotype significantly

Table 2. The Association between MC4R Genotype and Feed Intake, Nutrient Digestibility, FCR and Daily Weight Gain in 4-months Old

\begin{tabular}{|c|c|c|c|c|}
\hline \multirow{3}{*}{ Variable } & \multicolumn{4}{|c|}{ The genotype of SNP g.1079C/T } \\
\hline & \multicolumn{2}{|c|}{ Faculty of Animal Science ${ }^{\mathrm{ns}}$} & \multicolumn{2}{|c|}{ Banyusoco $^{\text {ns }}$} \\
\hline & $\begin{array}{c}\mathrm{CC} \\
(\mathrm{N}=17)\end{array}$ & $\begin{array}{c}\mathrm{CT} \\
(\mathrm{N}=6)\end{array}$ & $\begin{array}{c}\mathrm{CC} \\
(\mathrm{N}=18)\end{array}$ & $\begin{array}{c}\mathrm{CT} \\
(\mathrm{N}=5)\end{array}$ \\
\hline \multicolumn{5}{|c|}{$\begin{array}{l}\text { Feed intake }(\mathrm{g} / \mathrm{kg} \\
\left.\mathrm{BW}^{0.75} / \text { day }\right)\end{array}$} \\
\hline - DM & $76.07 \pm 8.38$ & $76.45 \pm 11.29$ & $69.33 \pm 14.19$ & $64.83 \pm 12.78$ \\
\hline - OM & $66.54 \pm 7.18$ & $67.31 \pm 8.83$ & $55.61 \pm 16.61$ & $50.99 \pm 5.99$ \\
\hline$-\mathrm{CP}$ & $13.40 \pm 1.65$ & $13.11 \pm 1.78$ & $7.92 \pm 2.67$ & $9.42 \pm 1.88$ \\
\hline$-\mathrm{EE}$ & $3.48 \pm 1.88$ & $3.42 \pm 0.91$ & $1.11 \pm 0.31$ & $1.33 \pm 0.32$ \\
\hline$-\mathrm{CF}$ & $11.39 \pm 2.06$ & $11.74 \pm 2.44$ & $13.34 \pm 5.28$ & $14.44 \pm 1.41$ \\
\hline - NFE & $47.51 \pm 2.06$ & $48.72 \pm 5.08$ & $76.84 \pm 38.21$ & $91.81 \pm 42.60$ \\
\hline - $\mathrm{TDN}$ & $58.23 \pm 7.68$ & $59.73 \pm 5.77$ & $38.32 \pm 11.68$ & $45.14 \pm 3.63$ \\
\hline \multicolumn{5}{|c|}{$\begin{array}{l}\text { Nutrient } \\
\text { digestibility (\%) }\end{array}$} \\
\hline - DM & $76.06 \pm 3.50$ & $76.39 \pm 4.85$ & $63.98 \pm 19.58$ & $72.12 \pm 8.25$ \\
\hline - OM & $84.51 \pm 6.68$ & $89.34 \pm 4.57$ & $49.29 \pm 23.95$ & $57.72 \pm 15.67$ \\
\hline$-\mathrm{CP}$ & $81.19 \pm 4.62$ & $81.26 \pm 5.09$ & $58.96 \pm 17.95$ & $67.75 \pm 8.07$ \\
\hline$-\mathrm{EE}$ & $89.80 \pm 6.83$ & $91.42 \pm 5.04$ & $44.48 \pm 26.73$ & $48.66 \pm 27.69$ \\
\hline$-\mathrm{CF}$ & $76.27 \pm 11.37$ & $84.02 \pm 4.86$ & $39.74 \pm 20.66$ & $46.66 \pm 22.95$ \\
\hline - NFE & $72.98 \pm 7.80$ & $74.53 \pm 7.50$ & $64.64 \pm 7.54$ & $64.10 \pm 5.32$ \\
\hline - $\mathrm{TDN}$ & $76.97 \pm 6.61$ & $78.81 \pm 5.34$ & $64.13 \pm 14.45$ & $62.77 \pm 8.77$ \\
\hline $\mathrm{ADG}(\mathrm{g})$ & $118.86 \pm 57.80$ & $85.83 \pm 34.51$ & $73.34 \pm 53.18$ & $111.96 \pm 30.6$ \\
\hline FCR & $4.83 \pm 2.60$ & $7.19 \pm 4.08$ & $10.46 \pm 13.69$ & $3.88 \pm 2.61$ \\
\hline
\end{tabular}

$\mathrm{DM}=$ dry matter; $\mathrm{OM}=$ organic matter; $\mathrm{CP}=$ crude protein; $\mathrm{EE}=$ extract ether; $\mathrm{CF}=$ crude fiber; $\mathrm{NFE}=$ nitrogen-free extract; $\mathrm{TDN}=$ total digestible nutrient; $\mathrm{ADG}=$ average daily gain; $\mathrm{FCR}=$ feed conversion ratio ${ }^{n s}$ Means non sigsificant 
affected the digestibility of DM, OM, and TDN in 7-month-old goats maintained in research cages $(\mathrm{P}<0.05)$ while CT genotype significantly affected the digestibility of DM, CP, NFE and TDN in 7month-old goats kept in Banyusoco. These study findings indicated that SNP g.1079C/G of MC4R gene had a significant association with the digestibility of DM, OM, and TDN in 7 months Bligon goats maintained in the research cage and the digestibility of DM, CP, NFE and TDN in 7 months Bligon goats kept in Banyusoco.

The result of the association between genotype MC4R gene and feed intake indicated no significant association in all fraction of feed intake in two location groups for 4 months groups (Table 2). This is because the goats in the study that were post-weaned goats, therefor the goats are adapting to consumption the forage. Ginting (2009) reported that kids can eat solid feed in 2-3 weeks of age. The relationship between genotype

Table 3. The Association between MC4R Genotype and Feed Intake, Nutrient Digestibility, FCR and Daily Weight Gain in 7-months Old

\begin{tabular}{|c|c|c|c|c|}
\hline \multirow{3}{*}{ Variable } & \multicolumn{4}{|c|}{ The genotype of SNP g.1079C/T } \\
\hline & \multicolumn{2}{|c|}{ Faculty of Animal Science } & \multicolumn{2}{|c|}{ Banyusoco } \\
\hline & $\begin{array}{c}\mathrm{CC} \\
(\mathrm{N}=15)\end{array}$ & $\begin{array}{c}\mathrm{CT} \\
(\mathrm{N}=5)\end{array}$ & $\begin{array}{c}\mathrm{CC} \\
(\mathrm{N}=18)\end{array}$ & $\begin{array}{c}\mathrm{CT} \\
(\mathrm{N}=5)\end{array}$ \\
\hline \multicolumn{5}{|c|}{$\begin{array}{l}\text { Feed intake }(\mathrm{g} / \mathrm{kg} \\
\left.\mathrm{BW}^{0.75} / \text { day }\right)\end{array}$} \\
\hline$-\mathrm{DM}$ & $89.25 \pm 9.28$ & $89.52 \pm 5.85$ & $43.47 \pm 12.91$ & $20.73 \pm 20.73$ \\
\hline$-\mathrm{OM}$ & $75.11 \pm 7.75$ & $75.20 \pm 4.82$ & $43.47 \pm 12.91$ & $52.41 \pm 19.91$ \\
\hline$-\mathrm{CP}$ & $15.77 \pm 2.34$ & $15.87 \pm 3.14$ & $5.22 \pm 2.31$ & $0.07 \pm 4.57$ \\
\hline$-\mathrm{EE}$ & $1.65 \pm 0.19$ & $1.60 \pm 0.09$ & $0.81 \pm 0.34$ & $1.03 \pm 0.64$ \\
\hline$-\mathrm{CF}$ & $15.94 \pm 2.01$ & $16.97 \pm 3.58$ & $11.12 \pm 3.60$ & $12.92 \pm 10.45$ \\
\hline - NFE & $56.69 \pm 5.85$ & $57.09 \pm 3.07$ & $24.98 \pm 7.99$ & $29.89 \pm 12.47$ \\
\hline$-\mathrm{TDN}$ & $60.98 \pm 7.08$ & $58.73 \pm 4.53$ & $27.53 \pm 9.93$ & $37.86 \pm 12.65$ \\
\hline \multicolumn{5}{|l|}{$\begin{array}{l}\text { Nutrient } \\
\text { digestibility (\%) }\end{array}$} \\
\hline - DM & $80.69 \pm 2.92^{\mathrm{a}}$ & $77.82 \pm 1.07^{\mathrm{b}}$ & $63.16 \pm 7.22^{\mathrm{x}}$ & $72.66 \pm 8.92^{y}$ \\
\hline - OM & $81.59 \pm 2.60^{\mathrm{a}}$ & $78.97 \pm 1.11^{\mathrm{b}}$ & $71.43 \pm 5.42$ & $77.78 \pm 8.77$ \\
\hline$-\mathrm{CP}$ & $87.21 \pm 2.94$ & $85.37 \pm 2.31$ & $70.28 \pm 7.77^{x}$ & $79.29 \pm 7.18^{y}$ \\
\hline$-\mathrm{EE}$ & $78.61 \pm 4.68$ & $75.27 \pm 4.35$ & $48.10 \pm 13.42$ & $58.57 \pm 22.69$ \\
\hline$-\mathrm{CF}$ & $73.62 \pm 4.57$ & $69.18 \pm 3.29$ & $58.53 \pm 11.05$ & $67.99 \pm 12.84$ \\
\hline - NFE & $61.67 \pm 2.73$ & $59.33 \pm 2.27$ & $61.06 \pm 8.4^{x}$ & $70.49 \pm 10.66^{\mathrm{y}}$ \\
\hline - TDN & $68.29 \pm 9.85^{\mathrm{a}}$ & $65.59 \pm 1.92^{b}$ & $62.46 \pm 8.5^{x}$ & $72.14 \pm 11.26^{\mathrm{y}}$ \\
\hline ADG (g) & $132.71 \pm 72.03$ & $70.42 \pm 46.97$ & $47.59 \pm 46.56$ & $53.83 \pm 37.84$ \\
\hline FCR & $10.62 \pm 15.97$ & $16.22 \pm 8.02$ & $10.39 \pm 6.97$ & $9.27 \pm 7.32$ \\
\hline
\end{tabular}

$\mathrm{DM}=$ dry matter; $\mathrm{OM}=$ organic matter; $\mathrm{CP}=$ crude protein; $\mathrm{EE}=$ extract ether; $\mathrm{CF}=$ crude fiber; $\mathrm{NFE}=$ nitrogen-free extract; $\mathrm{TDN}=$ total digestible nutrient; $\mathrm{ADG}=$ average daily gain; $\mathrm{FCR}=$ feed conversion ratio a,b Means with different superscripts in the same row at Faculty of Animal Science groups differ significantly $(\mathrm{P}<0.05)$.

$\mathrm{x}, \mathrm{y}$ means with different superscripts in the same row at Banyosoco groups differ significantly $(\mathrm{P}<0.05)$. 
MC4R and nutrient digestibility showed a significant association in several fractions of nutrient digestibility in two locations group for 7 months groups (Table 3 ). The significant effect can due to the work of the MC4R gene. The MC4R gene is a group of family protein-coupled receptors (GPCRs) that play a role in on feed intake and body weight in mammals (Dubern, 2015; Anderson et al., 2016). Feed intake is one of the influencing factors that determine the amount of digestibility (Toharmat et al., 2006). Houston et al. (2004) found an SNP at position 298 Asn/Asn in the pig. They concluded that animals with the Asn298/Asn298 genotype had a higher daily feed intake (DFI; $2.098 \mathrm{~g}$ ) than those with Asp298/Asp298 (1.933 g) and Asp298/Asn298 (2.071 g) genotype. In Italian pigs, Davoli et al. (2012) found a significant effect of SNP c.1426G/A on FCR $(\mathrm{p}<0.05)$ and daily weight gain $(\mathrm{p}<0.01)$. Davoli et al. (2012) reported that the highest mean value of FCR and daily weight gain was found in animals with AA genotype ( $N=293)$, followed by animals with $A G$ $(\mathrm{N}=288)$ and $\mathrm{GG}(\mathrm{N}=77)$ genotypes. Contrarily, an SNP g.1069C/G detected in cattle did not significantly affect FCR and daily weight gain.

\section{CONCLUSION}

There was no significant effect SNP g.1079C/T on feed intake, ADG, and FCR in Bligon. While the SNP g.1079C/T were significant association with the digestibility of $\mathrm{DM}, \mathrm{OM}$, and TDN of Bligon kept in the research cage and the digestibility of DM, CP, ETN, and TDN in Bligon kept in Banyusoco. Finally, SNP g.1079C/T can be used for Bligon goats genotyping, and as marker-assisted selection (MAS) for the analyzed traits in Bligon goats.

\section{ACKNOWLEDGMENTS}

The study was supported by the grant from the Indonesia Higher Education (Dikti) in Penelitian Disertasi Doktor (Doctoral Research Program) scheme with contract no. 2894/UN1.DITLIT/DIT-LIT/LT/2019. The authors thank Anisa Warih, Anis Nur Jannah, Huda, Hanif, Muhammad Fadil, Yasin Shihab, KhoirulAnam, Aji, and Fajar Aji Mukti for helping data collection. The authors are also grateful to RetnoSetyawati and Siti Zubaedah for aiding DNA analysis and proximate analysis.

\section{REFERENCES}

Anderson, E. J. P., I. Cakir, S. J. Carrington, R. D. Cone, M.G. Langroudi, T. Gillyard, L.E. Gimenez, and M. J. Litt. 2016. Regulation of feeding and energy homeostasis by $\alpha$ MSH. J. Mol. Endocrinal.,56 (4):157-174.

AOAC. 2005. Official Method of Analysis of the Association of Official Analytical Chemist. 18th ed. AOAC International. The United States of Amerika.

Astuti, M. 1980. Rancangan Percobaan dan Analisa Statistika. Bagian Pemuliaan Ternak Fakultas Peternakan Universitas Gadjah Mada. Yogyakarta.

Davoli R., S. Braglia, V. Valastro, C. Annarratone, M. Comella, P. Zambonelli, I. Nisi, M. Gallo, L. Buttazzoni, and V. Russo. 2012. Analysis of MC4R polymorphism in Italian Large White and Italian Duroc pigs: Association with carcass traits. Meat Sci. 90(4):887-89=

Dubern, B. 2015. MC4R, and MC3R Mutations. In M.L. Frelut (Ed.), The ECOG's eBook on Child and Adolescent Obesity. Available at ebook.ecog-obesity.eu. Access date, 9 February, 2016.

Hardjosubroto, W. 1994. Aplikasi Pemuliaan Ternak di Lapangan. Grasindo. Jakarta, 210-227.

Latifah, L., D. A. Priyadi, A. Kustantinah, D. Maharani, and T. Hartatik. 2017. Genetic Analysis Using Partial Sequencing of Melanocortin 4 Receptor (MC4R) Gene in Bligon Goat. Media Peternakan. 40(2):7177.

Latifah, L., A. Kustantinah, D. Maharani, and T. Hartatik. 2018. Association of Melanocortin 4 Receptor gene polymorphism with growth traits in Bligon goat. J. Indonesian Trop. Anim. Agric. 43(4): 343-351.

Maharani, D., A. Fathoni, Sumadi, T. Hartatik, and M. Khusnudin. 2018. Identification of MC4R gene and its association with body weight and body size in Kebumen Ongole Grade cattle. J. Indonesian Trop. Anim. Agric. 43(2):87-93.

Melnikova, E.E., N.V. Bardukov, M.S. Fornara, O.V. Kostyunina, A.A. Sermyagin1, A.M. Zaitsev, N.A. Zinovieva1. 2018. Effects of genotypes For IGF2, CCKAR and MC4R on the phenotypic estimations and breeding values for productive traits in pigs. 
Agricultural Biology. 54(4):723-734.

Panda, S., G.K. Gaur, N.R. Sahoo, and B.L. Saini. 2019. Association of MC4R, RYRI and $P R K A G 3$ single nucleotide polymorphisms with body weight in crossbred piglets. Indian J. Anim. Sci. 89(5):539-542.

Prihandini, P.W., S. Sumadi, G. Suparta, and D. Maharani. 2019. Melanocortin-4 Receptor (MC4R) gene polymorphism and its effect on growth traits in Madura cattle. J. Indonesian. Trop. Ani. Agri. 44(1):38-46.

Shishay, G., G. Liu, X. Jiang, Y. Yu, W. Teketay, D. Du, H. Jing, and C. Liu. 2019. Variation in the Promoter Region of the MC4R Gene Elucidates the Association of Body Measurement Traits in $\mathrm{Hu}$ Sheep. Int. J. Mol. Sci. 20(2): 1-18-

Song, X. M., J. F. Jiang, G. Z. Zhang, F. X. Shiand, and Y. Q. Jiang. 2012. DNA polymorphisms of the $\mathrm{Hu}$ sheep melanocortin-4 receptor gene associated with birth weight and 45-day weaning weight. J. Gen. Mol. Res., 11(4):44324441.

Tillman, A. D., H. Hartadi, S. Reksohadiprodjo, S. Prawirokusumo and S. Lebdosoekojo. 1998. Ilmu MakananTernak Dasar. Gadjah MadaUniversty Press. Yogyakarta. 249259.

Toharmat, T, E. Nursasih, R. Nazilah, N.Hotimah, T.Q. Noerzihad, N.A. Sigit, and Y. Retnani. 2006. Sifat Fisik Pakan Kaya Serat dan Pengaruhnya terhadap Konsumsi dan Kecernaan Nutrien Ransum pada Kambing. Media Peternakan. 29(3):146-154.

Wang, Y., C. Wang, J. Zhang, C. Meng, X. Zhang, Z. Wang, Y. Fang, D. Mao and S. Cao. 2015. Three novel MC4R SNPs associated with growth traits in $\mathrm{Hu}$ sheep and East Friesian $\mathrm{x} \mathrm{Hu}$ crossbreed sheep. Small Rum. Res. 125(1):26-33. 